\title{
The effects of 5-HT on cholinergic contraction in human airways in vitro
}

\author{
L.J. Dupont*, J.L. Pype*, M.G. Demedts*, P. De Leyn**, G. Deneffe**, G.M. Verleden*
}

The effects of 5-HT on cholinergic contraction in human airways in vitro. L.J. Dupont, J.L. Pype, M.G. Demedts, P. De Leyn, G. Deneffe, G.M. Verleden. (C) ERS Journals Ltd. 1999.

ABSTRACT: Inhaled 5-hydroxytryptamine (5-HT) causes bronchoconstriction in asthmatics, and 5-HT plasma levels are elevated in asthma. Electrical field stimulation (EFS) of human airways, in vitro, evokes cholinergic contraction mediated by the release of acetylcholine (Ach) from postganglionic cholinergic nerves. The present study investigates whether selective 5-HT agonists and antagonists can modulate EFSinduced cholinergic contraction in human airways in vitro.

Human airways, obtained from resections for bronchial carcinoma or organ transplant donors, were suspended under 2 -g tension, between two platinum wire electrodes, in carbogenated Krebs solution at $37^{\circ} \mathrm{C}$ and EFS was applied (1-32 $\mathrm{Hz}, 50$ $\mathrm{V}, 0.5 \mathrm{~ms}, 15 \mathrm{~s}$ every $4 \mathrm{~min}$ ) to elicit cholinergic contractions.

5-HT $(10 \mu M-0.3 \mathrm{mM})$ produced frequency- and concentration-dependent facilitation of cholinergic contraction, but did not displace the concentration/response curve to Ach. Tropisetron $(1 \mu \mathrm{M})$, a $5-\mathrm{HT}_{3}$ and $5-\mathrm{HT}_{4}$ antagonist, completely blocked the facilitatory effect of 5-HT $(100 \mu \mathrm{M})$, whereas both ondansetron $(\mathrm{l} \mu \mathrm{M})$ and GR 125478D $(1 \mu \mathrm{M})$, a selective $5-\mathrm{HT}_{3}$ and $5-\mathrm{HT}_{4}$ antagonist, respectively, also attenuated the 5-HT-induced enhancement of cholinergic contraction. This facilitatory effect of 5HT was partially mimicked by both selective 5-HT 3 (2-methyl-5-HT) and 5-HT (RS 67333 and 5-methoxytryptamine) agonists. Fluoxetine $(10 \mu \mathrm{M})$, a 5-HT uptake inhibitor, had no effect on the 5-HT (10-100 $\mu \mathrm{m})$ induced potentiation of cholinergic contraction.

These findings suggest that 5-HT facilitates cholinergic contraction in human airways in vitro through stimulation of both prejunctional $5-\mathrm{HT}_{3}$ and $5-\mathrm{HT}_{4}$ receptors. This may implicate a role of 5-HT in asthma.

Eur Respir J 1999; 14: 642-649.
*Pulmonary Pharmacology Unit, Laboratory of Pneumology and **Dept of Thoracic Surgery, University Hospital Gasthuisberg, Katholieke Universiteit Leuven, Belgium.

Correspondence: G.M. Verleden

Laboratory of Pneumology

Campus Gasthuisberg $\mathrm{O} / \mathrm{N}$

49 Herestraat

B-3000 Leuven

Belgium

Fax: 3216346803

Keywords: Cholinergic contraction

fluoxetine

5-hydroxytryptamine

5 -hydroxytryptamine $3 / 5$ -

hydroxytryptamine 4

human airways

Received: June 171998

Accepted after revision March 151999

J.L. Pype is funded by GlaxoWellcome, Belgium. G.M. Verleden is holder of the GlaxoWellcome leerstoel voor respiratoire farmacologie at the Katholieke Universiteit Louvain, Belgium.
Following the isolation and synthesis of 5-hydroxytryptamine (5-HT) in the early $1950 \mathrm{~s}$, there has been increasing interest and research into the physiological functions of this biogenic amine. 5-HT is found in large amounts in enterochromaffin cells throughout the gastrointestinal tract, in blood platelets and in specific regions of the central nervous system [1]. The presence of 5-HT has also been demonstrated in the lung, although its exact role in the respiratory system remains unclear [2].

5-HT exhibits a broad diversity of effects on airway smooth muscle contraction, which seems to implicate the presence of a wide variety of 5-HT receptor subtypes in both airway smooth muscle and efferent nerves and which also appears to be species-dependent. In several animal airways, 5-HT acts directly on airway smooth muscle, causing contraction at low doses and relaxation at high doses. Both contraction and relaxation are mediated by stimulation of the $5-\mathrm{HT}_{2 \mathrm{~A}}$ receptor on airway smooth muscle [3]. The effects of 5-HT on airway smooth muscle contraction may also be attributed, in part, to the ability of 5 -HT to modulate the contractile and relaxing response to other neurotransmitters. 5-HT has been shown to modulate nonadrenergic noncholinergic (NANC) contraction in guinea-pig airways in vitro. This contraction, mediated by the release of neuropeptides from sensory nerve endings [4], was shown to be significantly inhibited by stimulation of a prejunctional 5-HT receptor, which was originally described as a $5-\mathrm{HT}_{1}$-like subtype [5] but should probably be considered as a $5-\mathrm{HT}_{7}$ receptor on the basis of its pharmacological profile [6]. 5-HT has also been shown to modulate cholinergic neural responses in a number of species by interacting with presynaptic neuronal 5-HT receptors. The 5-HT receptor subtype involved appears to differ according to the nature of the species. In mouse isolated tracheal segments, 5-HT potentiates cholinergic contraction by activating presynaptic $5-\mathrm{HT}_{1}-$ like receptors [7]. In rat bronchi 5-HT enhances cholinergic contraction by stimulation of $5-\mathrm{HT}_{2}$ receptors [8]. Conversely, in guinea-pig airways, several authors have demonstrated facilitatory effects of 5-HT on postganglionic cholinergic neurotransmission by stimulation of 5$\mathrm{HT}_{3}$ receptors $[9,10]$.

Although the effects of 5-HT on airway calibre have been extensively studied in several animal species, both in vivo and in vitro, the situation is less well established in humans. A possible relationship between 5-HT and airway obstruction has been suggested on the basis of the association of wheezing with carcinoid syndrome, although it 
is now obvious that other mediators such as histamine, bradykinin and tachykinins are also released in this pathology [11]. Inhaled 5-HT does not produce bronchoconstriction in normal subjects [12]. It has been demonstrated in some studies, however, that inhalation of 5-HT causes bronchoconstriction in $10-65 \%$ of asthmatic patients, whereas other investigators have found no response [12]. An elevated plasma level of 5-HT has been documented in symptomatic asthmatic patients when compared to nonasthmatics. In the former group, the 5-HT level significantly correlated with clinical severity rating and forced expiratory volume in one second (FEV1) [13]. Despite these findings, 5-HT antagonists are not routinely used in asthma therapy, although beneficial effects of ketanserin, a $5-\mathrm{HT}_{2}$ antagonist, have been noted on FEV1 in patients with chronic airflow limitation [14]. In excised human airways in vitro facilitatory effects of relatively high concentrations of 5-HT were observed, which were, in accordance with the receptor subtype found in guinea-pig airways, attributed to an effect on $5-\mathrm{HT}_{3}$ receptors [10]. However, in this study, only a limited range of 5-HT agonists and antagonists was used and it remains to be established whether the $5-\mathrm{HT}_{3}$ receptor subtype is exclusively responsible for the observed effects of 5-HT on cholinergic contraction in human airways.

The aim of the present study was to investigate the effects of 5-HT on cholinergic contraction elicited by electrical field stimulation (EFS) at different frequencies of stimulation in human airways in vitro and to characterize the receptor subtype involved by using selective 5-HT agonists and antagonists, listed in table 1 . The effects of pretreatment with fluoxetine, a selective 5-HT reuptake inhibitor, on the 5-HT-induced effect on cholinergic contraction were also of interest, as it has previously been demonstrated that fluoxetine enhances 5-HT inhibition of NANC contraction in guinea-pig airways in vitro [17].

\section{Methods}

\section{Preparation of tissue}

Macroscopically normal bronchial tissue was obtained from thoracotomy specimens from patients (three females, 17 males; mean \pm SEM age $65 \pm 8$ yrs, 14 smokers $45 \pm 6$ (packyrs)) undergoing surgery for resection of bronchial carcinoma. Main bronchi were also obtained from three patients (one female, two males) who were used as transplant donors. None of the patients showed characteristics of asthma. Immediately after surgical resection, a macroscopically normal part of the lung tissue was immersed in cooled $\left(4{ }^{\circ} \mathrm{C}\right)$ and carbogenated $\left(5 \% \mathrm{CO}_{2}, 95 \% \mathrm{O}_{2}\right)$ modified Krebs-Henseleit buffer solution of the following composition (mM): $\mathrm{NaCl} 118, \mathrm{KCl} 5.9, \mathrm{MgSO}_{4} 1.2, \mathrm{CaCl}_{2} 2.5$, $\mathrm{NaH}_{2} \mathrm{PO}_{4}$ 1.2, $\mathrm{NaHCO}_{3} 25.5$, and dextrose 5.5 (pH 7.4). The tissue remained in fresh carbogenated buffer throughout the dissection procedure and during the experiments and was used 1-18 $\mathrm{h}$ after resection. Just prior to the experiments, the airways were carefully stripped from surrounding lung tissue and cut into strips (main bronchi) or ring segments (segmental and subsegmental bronchi). The bronchial preparations were mounted between two platinum wire electrodes (separated by $1.0 \mathrm{~cm}$ ) in $10-\mathrm{mL}$ organ baths containing modified Krebs-Henseleit solution, which
Table 1. - Selective agonists and antagonists and their potency at human 5 -hydroxytryptamine $(5-\mathrm{HT})_{3}$ and $5-\mathrm{HT}_{4}$ receptors.

\begin{tabular}{lcc}
\hline & $5-\mathrm{HT}_{3}$ & $5-\mathrm{HT}_{4}$ \\
\hline Agonists* & & \\
5-HT & $\mathrm{NA}$ & 8.2 \\
2-Methyl-5-HT & 7.7 & $<<4$ \\
5-Methoxytryptamine & Inactive & 7 \\
RS67333 & $\mathrm{NA}$ & 8.7 \\
RU24969 & Inactive & Inactive \\
Sumatriptan & Inactive & Inactive \\
Antagonists & & \\
Tropisetron & 10.6 & 6.2 \\
Ondansetron & 8.6 & $<<5$ \\
Methysergide & Inactive & Inactive \\
\hline
\end{tabular}

*: $\mathrm{pEC}_{50}$, the negative logarithm of the molar concentration of an agonist that produces $50 \%$ of the maximal effect; ${ }^{+}: \mathrm{pA}_{2}$, the negative logarithm of the molar concentration of an antagonist that produces a two-fold shift to the right in the agonist doseresponse curve; NA: not available. (Adapted from $[15,16]$.)

was maintained at $37^{\circ} \mathrm{C}$ and continuously bubbled with $5 \%$ $\mathrm{CO}_{2}$ in $\mathrm{O}_{2}$. Thin silk threads were tied to both ends of the strips and passed through and tied to the bronchial rings. One thread was connected to a steel hook at the bottom of the organ bath and the other was connected a Grass FT 03 force-displacement transducer (Stag Instruments, Chalgrove, UK). The preparations contracted against a load of $2 \mathrm{~g}$, which has previously been shown to produce optimal repeatable responses in similar preparations [18]. While being washed with fresh buffer solution every $20 \mathrm{~min}$, tissues were allowed to equilibrate under tension for $\geq 60$ min before the experimental protocols were started, during which time a stable baseline tension was achieved.

\section{Experimental protocol}

The experimental protocol was identical for bronchial strip and bronchial ring preparations.

Isometric contractile responses, induced by either EFS or adding acetylcholine (Ach), were measured using a force-displacement transducer. The traces were visualized on a computer screen after digitalization of the signal (Codas; Dalaq Instrument, Inc., Akron, OH, USA) and recorded on a personal computer.

Electrical field stimulation. EFS was produced using a Harvard student stimulator (Harvard Apparatus, Edenbridge, UK). Biphasic square-wave pulses at a supramaximal voltage of $50 \mathrm{~V}$ at source and a pulse duration of $0.5 \mathrm{~ms}$ were delivered for $15 \mathrm{~s}$ every $4 \mathrm{~min}$ at frequencies ranging $1-32 \mathrm{~Hz}$.

Eight tissues were simultaneously tested with at least one time control tissue per experiment. These time control tissues were treated with EFS and served to demonstrate the stability of the response. After the equilibration period, a frequency/response curve $(1-32 \mathrm{~Hz})$ was constructed and discarded. After washing the tissues, a control frequency/ response curve was constructed. In a first set of experiments, 5-HT (3-300 $\mu \mathrm{M})$ was added to the organ baths, using one concentration of drug with each tissue preparation. After an incubation period of $15 \mathrm{~min}$, a third frequency/response curve was obtained. Preliminary experiments involving the time course of the stimulatory effects of 
5-HT demonstrated no further facilitation of the cholinergic contraction with longer incubation time.

In a second set of experiments, the tissues were pretreated with the specific 5-HT antagonists methysergide $\left(1 \mu \mathrm{M}, 5-\mathrm{HT}_{1}, 5-\mathrm{HT}_{2}, 5-\mathrm{HT}_{7}\right.$ selective), tropisetron $(1 \mu \mathrm{M}$, $5-\mathrm{HT}_{3}, 5-\mathrm{HT}_{4}$ selective), ondansetron $\left(1 \mu \mathrm{M}, 5-\mathrm{HT}_{3}\right.$ selective) and GR 125487D (1 $\mu \mathrm{M}, 5-\mathrm{HT}_{4}$ selective), each for $15 \mathrm{~min}$, before 5-HT was added. The same protocol was used as above. Control tissues were treated with antagonists alone.

In a third set of experiments, the effect of the selective 5HT agonists 2-methyl-5-HT (1-100 $\mu \mathrm{M}, 5-\mathrm{HT}_{3}$ selective), 5-methoxytryptamine $\left(1-100 \mu \mathrm{M}, 5-\mathrm{HT}_{2}, 5-\mathrm{HT}_{4}\right.$ selective), RS $67333\left(1-100 \mu \mathrm{M}, 5-\mathrm{HT}_{4}\right.$ selective), sumatriptan (1-100 $\mu \mathrm{M}, 5-\mathrm{HT}_{1 \mathrm{~B} / 1 \mathrm{D}}$ selective) and RU-24969 (1-100 $\mu \mathrm{M}, 5-\mathrm{HT}_{1 \mathrm{~A} / 1 \mathrm{~B}}$ selective), was studied on the cholinergic contraction elicited by EFS.

A fourth set of experiments investigated the effect of pretreatment with fluoxetine $(10 \mu \mathrm{M}$, a selective 5-HT uptake inhibitor) on the 5-HT-induced effects on cholinergic contraction in the same manner as above.

Cumulative concentration/response curve to acetylcholine. To determine whether the effects of 5-HT on cholinergic contraction were due to activation of pre- or postjunctional receptors, the effect of a 15-min incubation period with 5-HT $(300 \mu \mathrm{M})$ was studied on the cumulative concentration/contraction relationship to exogenously applied Ach and was compared to contractile responses to Ach in untreated tissues from the same specimen. A cumulative concentration/effect curve to Ach was obtained by adding incremental concentrations, spaced at half $\log _{10}$ intervals $(30 \mathrm{nM}-30 \mathrm{mM})$, to the organ bath. Increasing concentrations of Ach were added until a plateau contraction was reached. The results were expressed as a percentage of the maximum contraction response to Ach $(10 \mathrm{mM})$, which was determined at the beginning of the experiment.

\section{Drugs}

Drugs used in these experiments were obtained from the following sources: 5-HT, Ach (Sigma Chemical Co., Eupen, Belgium); hexamethonium, tetrodotoxin ((Biomol), Sanver Tech, Boechout, Belgium); methysergide maleate, 2-methyl-5-HT, 5-methoxytryptamine ((Research Biochemicals International), Sanver Tech, Boechout, Belgium); RS67333 (Tocris Cookson, Langford, UK); tropisetron (ICS205-930) (a kind gift from Sandoz-Novartis, Basle, Switzerland); fluoxetine (LY110140) (a kind gift from Lilly Research Laboratories, Indianapolis, IN, USA); and ondansetron (GR 38032F), GR125478D, sumatriptan (GR 43175C) (a kind gift from GlaxoWellcome, Stevenage, UK). Compound RU-24969 was provided by Research Biochemicals International as part of the Chemical Synthesis Program of the National Institute of Mental Health, contract N01MH30003. Tropisetron was dissolved in dimethyl sulphoxide. All other drugs were dissolved in distilled water. Fresh drug solutions were made up daily. Drug additions did not exceed $1 \%$ of the organ bath volume. All concentrations refer to the final organ bath concentration.

\section{Analysis of results}

Results are expressed as mean \pm SEM. All contractile responses were measured as the difference between the peak tension and the resting tension that developed. The effects of single concentrations of 5-HT or 5-HT agonists with or without antagonist or fluoxetine were expressed as percentage facilitations, comparing the contractile responses at each stimulation frequency after pretreatment with the contraction at the same frequency in the control. Since each tissue acted as its own control, analysis of data was possible using a Student's t-test for paired data. The significance of difference between tissues treated with 5HT with or without antagonists or fluoxetine was assessed using a Student's t-test for unpaired data. The same test was used to assess the effect of 5-HT versus control on the cumulative dose/response curve to exogenous Ach. A pvalue of $<0.05$ was considered significant.

\section{Results}

In isolated human airways, EFS $(50 \mathrm{~V}, 0.5 \mathrm{~ms}, 1-32 \mathrm{~Hz}$ for $15 \mathrm{~s}$ every $4 \mathrm{~min}$ ) caused a rapid contraction that was abolished by pretreatment of the tissues for $10 \mathrm{~min}$ with atropine $(1 \mu \mathrm{M})$, confirming that the contractile response was caused by the release of Ach. Incubation with hexamethonium $(10 \mu \mathrm{M})$, a ganglion blocker, for $10 \mathrm{~min}$ had no effect on cholinergic contraction elicited by EFS $(50 \mathrm{~V}, 0.5 \mathrm{~ms}, 1-32 \mathrm{~Hz}$ for $15 \mathrm{~s}$ every $4 \mathrm{~min}$ ), confirming that the contractile responses were mediated by the release of Ach from postganglionic cholinergic nerves. The responses to EFS ( $50 \mathrm{~V}, 0.5 \mathrm{~ms}, 1-32 \mathrm{~Hz}$ for $15 \mathrm{~s}$ every $4 \mathrm{~min}$ ) were also completely blocked after $10 \mathrm{~min}$ incubation with tetrodotoxin $(1 \mu \mathrm{M})$, confirming their neuronal origin.

Effect of 5-hydroxytryptamine on cholinergic contraction in human airways in vitro

EFS ( $50 \mathrm{~V}, 0.5 \mathrm{~ms}, 1-32 \mathrm{~Hz}$ for $15 \mathrm{~s}$ every $4 \mathrm{~min}$ ) of human airways resulted in rapid cholinergic contraction,

a)

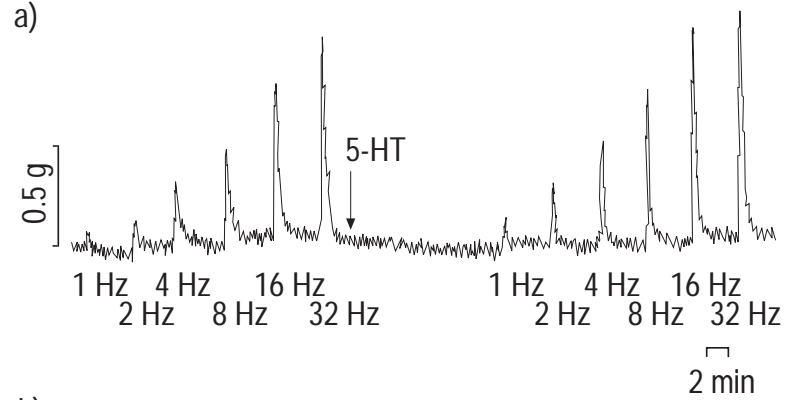

b)

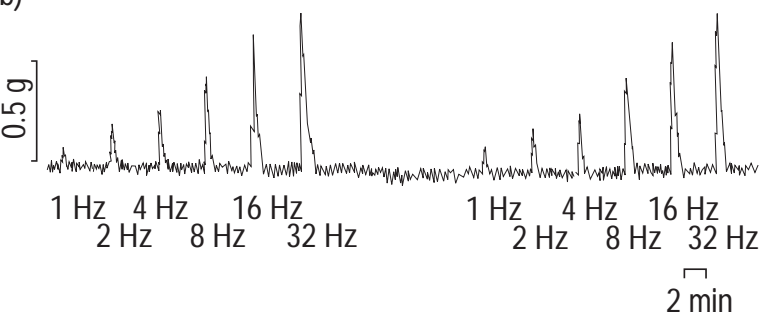

Fig. 1. - Trace showing the effect of 5-hydroxytryptamine (5-HT; 100 $\mu \mathrm{M})$ on cholinergic contraction elicited by electrical field stimulation (EFS) $(50 \mathrm{~V}$ at source, $0.5 \mathrm{~ms}, 1-32 \mathrm{~Hz}$ for $15 \mathrm{~s}$ every $4 \mathrm{~min}$ ) in human airways in vitro. a) 5-HT produced marked facilitation of cholinergic contraction. b) The response to EFS in control tissues remained stable. 
Table 2. - The effect of 5-hydroxytryptamine (5-HT) on electrical field stimulation (EFS)-induced contractile responses at different frequencies of stimulation in human airways in vitro

\begin{tabular}{|c|c|c|c|c|c|c|c|c|c|c|c|c|}
\hline & \multicolumn{12}{|c|}{ Contractile response* \% } \\
\hline & \multicolumn{2}{|c|}{$1 \mathrm{~Hz}$} & \multicolumn{2}{|c|}{$2 \mathrm{~Hz}$} & \multicolumn{2}{|c|}{$4 \mathrm{~Hz}$} & \multicolumn{2}{|c|}{$8 \mathrm{~Hz}$} & \multicolumn{2}{|c|}{$16 \mathrm{~Hz}$} & \multicolumn{2}{|r|}{$32 \mathrm{~Hz}$} \\
\hline & Pre & Post & Pre & Post & Pre & Post & Pre & Post & Pre & Post & Pre & Post \\
\hline 5-HT & & & & & & & & & & & & \\
\hline $\begin{array}{l}300 \mu \mathrm{M} \\
5-\mathrm{HT}\end{array}$ & $8.5 \pm 3.8$ & $17.4 \pm 5.1^{*}$ & $19.4 \pm 8.4$ & $37.1 \pm 10.8^{*}$ & $35.6 \pm 11.2$ & $62.2 \pm 15.9^{*}$ & $48.4 \pm 6.4$ & $72.8 \pm 7.0^{+}$ & $64.3 \pm 5.1^{+}$ & $89.9 \pm 4.9$ & 100 & $128.6 \pm 15.8^{*}$ \\
\hline $\begin{array}{l}100 \mu \mathrm{M} \\
5-\mathrm{HT}\end{array}$ & $4.7 \pm 1.0$ & $9.1 \pm 2.0$ & $12.1 \pm 2.9$ & $19.8 \pm 4.1^{+}$ & $23.4 \pm 3.9$ & $37.0 \pm 4.6^{+}$ & $41.1 \pm 4.6$ & $58.7 \pm 4.7^{+}$ & $70.2 \pm 3.8$ & $90.6 \pm 4.1^{+}$ & 100 & $115.7 \pm 1.3 *$ \\
\hline $\begin{array}{l}30 \mu \mathrm{M} \\
5-\mathrm{HT}\end{array}$ & $12.2 \pm 2.7$ & $18.8 \pm 3.9^{+}$ & $18.8 \pm 5.5$ & $24.3 \pm 6.1 *$ & $28.4 \pm 5.7$ & $37.6 \pm 5.7 *$ & $50.4 \pm 6.8$ & $60.1 \pm 6.7 *$ & $74.2 \pm 7.0$ & $90.3 \pm 5.9 *$ & 100 & $112.1 \pm 2.4^{*}$ \\
\hline $10 \mu \mathrm{M}$ & $13.2 \pm 2.5$ & $15.4 \pm 2.4$ & $23.6 \pm 3.9$ & $26.7 \pm 3.5$ & $44.6 \pm 3.3$ & $49.7 \pm 2.5^{*}$ & $66.2 \pm 3.6$ & $70.9 \pm 1.8$ & $86.8 \pm 2.0$ & $90.1 \pm 2.4$ & 100 & $104.6 \pm 1.5$ \\
\hline $\begin{array}{l}\text { Time } \\
\text { control }\end{array}$ & $6.7 \pm 1.7$ & $7.0 \pm 3.1$ & $15.9 \pm 2.7$ & $17.4 \pm 4.2$ & $34.6 \pm 2.2$ & $36.7 \pm 3.7$ & $42.8 \pm 1.7$ & $44.5 \pm 2.1$ & $80.8 \pm 3.4$ & $82.4 \pm 2.9$ & 100 & $101.7 \pm 1.1$ \\
\hline
\end{tabular}

Data are presented as mean \pm SEM. *: \% of maximal cholinergic contraction caused by EFS at $32 \mathrm{~Hz}$; all stimulation at $50 \mathrm{~V}$ at source, 0.5 ms, $1-32 \mathrm{~Hz}$ for $15 \mathrm{~s}$ every $4 \mathrm{~min}$. Pre: baseline response; Post: response after incubation with 5-HT. ${ }^{*}: \mathrm{p}<0.05 ;{ }^{+}: \mathrm{p}<0.01 ;{ }^{*}: \mathrm{p}<0.001$ versus control.

which increased in amplitude with increasing frequencies of stimulation. A typical trace is shown in figure 1, which also demonstrates the effect of 5-HT $(100 \mu \mathrm{M})$ on the baseline tension as well as on cholinergic response. 5-HT produced no statistically significant effect on baseline tension in human airways, although there was a trend towards a small relaxatory effect at high concentrations $(>100 \mu \mathrm{M})$. 5-HT $(100 \mu \mathrm{M})$ facilitated cholinergic contraction at all frequencies of stimulation. When results were expressed as \% facilitation, there was a more pronounced effect at lower frequencies of stimulation. However, when expressing the results as a percentage of the maximal contraction at $32 \mathrm{~Hz}$, the increase was more pronounced at higher frequencies (table 2).

5-HT $(10-300 \mu \mathrm{M}, \mathrm{n} \geq 5)$ produced a concentrationdependent increase in cholinergic contraction induced by EFS ( $50 \mathrm{~V}, 0.5 \mathrm{~ms}, 1-32 \mathrm{~Hz}$ for $15 \mathrm{~s}$ every $4 \mathrm{~min}$ ) in human airways in vitro, with a maximum facilitatory effect of $104 \pm 13 \%$ at $1 \mathrm{~Hz}$ at a concentration of $300 \mu \mathrm{M}$ (fig. 2).

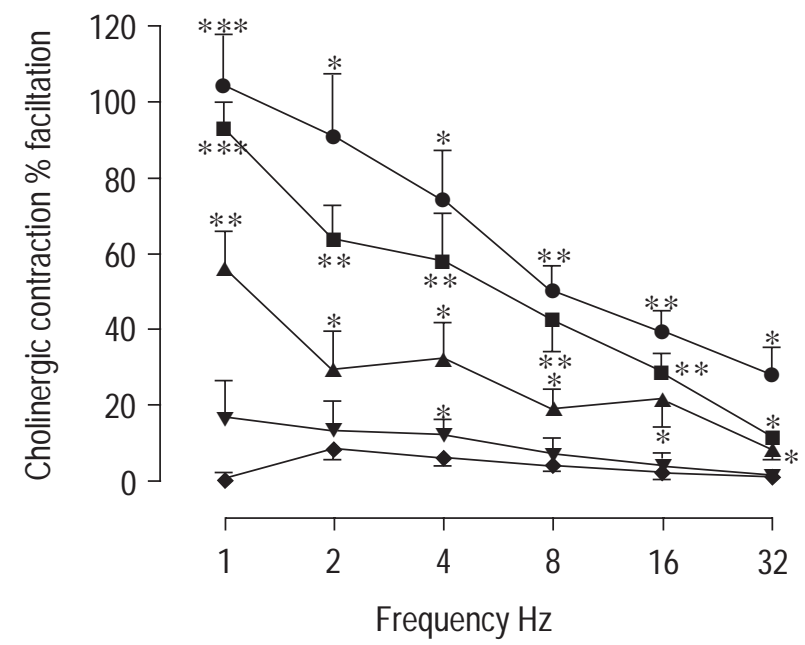

Fig. 2. - Effect of 5-hydroxytryptamine (5-HT; 10-300 $\mu \mathrm{M})$ on cholinergic contraction elicited by electrical field stimulation (EFS) (50 $\mathrm{V}$ at source, $0.5 \mathrm{~ms}, 0.5-32 \mathrm{~Hz}$ for $15 \mathrm{~s}$ every $4 \mathrm{~min}$ ) in human airways in vitro. 5-HT produced a concentration-dependent facilitation of cholinergic contraction. Data are presented as mean \pm SEM. : $300 \mu \mathrm{M}(\mathrm{n}=5)$; $\mathbf{\square}: 100 \mu \mathrm{M}(\mathrm{n}=8) ; \boldsymbol{\Delta}: 30 \mu \mathrm{M}(\mathrm{n}=6) ; \boldsymbol{\nabla}: 10 \mu \mathrm{M}(\mathrm{n}=6) ; \bullet:$ control tissues $(\mathrm{n}=10)$.
The responses to EFS $(50 \mathrm{~V}, 0.5 \mathrm{~ms}, 1-32 \mathrm{~Hz}$ for $15 \mathrm{~s}$ every $4 \mathrm{~min})$ in vehicle-treated tissues $(\mathrm{n}=8)$ remained stable throughout the period of the experiment. The different airway preparations behaved similarly in relation to the degree of facilitation of cholinergic contraction induced by 5-HT, as was evident from our data: 5-HT 100 $\mu \mathrm{M}$ at $16 \mathrm{~Hz}$ in airway strips versus bronchial ring segments: $31 \pm 9(n=3)$ versus $27 \pm 5 \%$ facilitation $(n=5$, NS).

Effect of 5-hydroxytryptamine antagonists on 5-hydroxytryptamine-facilitation of cholinergic contraction in human airways in vitro

Addition of methysergide ( $1 \mu \mathrm{M}, \mathrm{n}=5)$, a $5-\mathrm{HT}_{1}, 5-\mathrm{HT}_{2}$, $5-\mathrm{HT}_{7}$ antagonist, alone had no significant effect on either

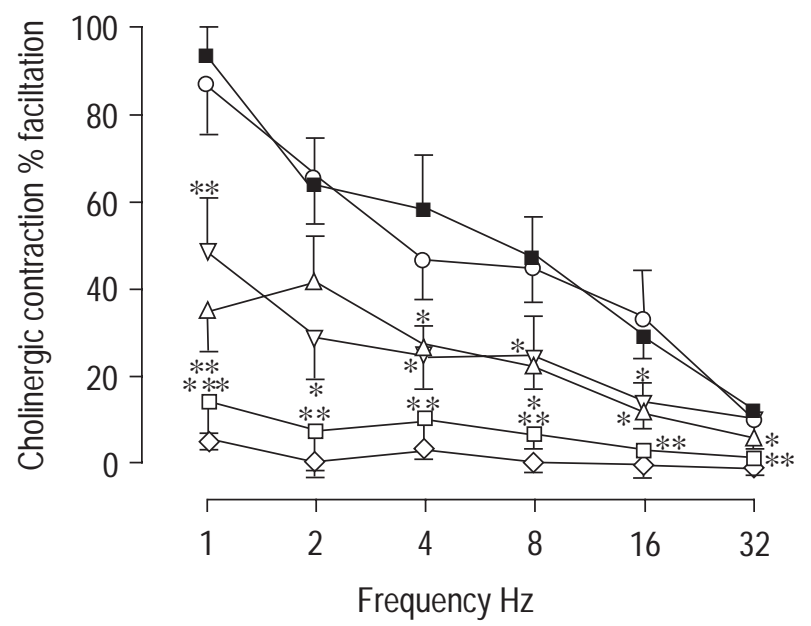

Fig. 3. - Facilitatory effect of 5-hydroxytryptamine (5-HT) $100 \mu \mathrm{M}(\mathbf{\square}$, $\mathrm{n}=8$ ) on cholinergic contraction elicited by electrical field stimulation (EFS) ( $50 \mathrm{~V}$ at source, $0.5 \mathrm{~ms}, 0.5-32 \mathrm{~Hz}$ for $15 \mathrm{~s}$ every $4 \mathrm{~min}$ ) in human airways in vitro and effect of pretreatment with selective 5-HT antagonists. Tropisetron $1 \mu \mathrm{M}(\square, \mathrm{n}=5)$ inhibited the 5-HT $(100$ $\mu \mathrm{M})$-induced effect. Methysergide $1 \mu \mathrm{M}(\mathrm{O}, \mathrm{n}=5)$ had no effect on facilitation of cholinergic contraction by 5 -HT $(100 \mu \mathrm{M})$. Pretreatment with either ondansetron $1 \mu \mathrm{M}(\triangle, \mathrm{n}=6)$ or GR 125478D $1 \mu \mathrm{M}(\nabla, \mathrm{n}=6)$ also had a significant inhibitory effect on facilitation of cholinergic contraction by 5 -HT. The responses in control tissues $(\diamond, n=8)$ remained stable. Data are presented as mean \pm SEM. *: $\mathrm{p}<0.05$; **: $\mathrm{p}<0.01$; ***: $\mathrm{p}<0.001$ versus $5-\mathrm{HT}$. 
basal tone or cholinergic contraction elicited by EFS ( $50 \mathrm{~V}$, $0.5 \mathrm{~ms}, 1-32 \mathrm{~Hz}$ for $15 \mathrm{~s}$ every $4 \mathrm{~min}$ ) in human airways in vitro. Methysergide also failed to prevent the 5-HTinduced increase in cholinergic contraction (fig. 3).

Tropisetron $(1 \mu \mathrm{M}, \mathrm{n}=5)$, a $5-\mathrm{HT}_{3}, 5-\mathrm{HT}_{4}$ antagonist, alone had no significant effect on either basal tone or cholinergic contraction induced by EFS in human airways in vitro $(50 \mathrm{~V}, 0.5 \mathrm{~ms}, 1-32 \mathrm{~Hz}$ for $15 \mathrm{~s}$ every $4 \mathrm{~min})$ but completely blocked the facilitatory effect of 5-HT (100 $\mu \mathrm{M}, \mathrm{n}=5$ ) on cholinergic contraction (fig. 3 ).

Ondansetron $(1 \mu \mathrm{M}, \mathrm{n}=6)$, a $5-\mathrm{HT}_{3}$ antagonist, and GR 125478D ( $1 \mu \mathrm{M}, \mathrm{n}=6)$, a $5-\mathrm{HT}_{4}$ antagonist, alone did not significantly affect basal tone or cholinergic contraction produced by EFS $(50 \mathrm{~V}, 0.5 \mathrm{~ms}, 1-32 \mathrm{~Hz}$ for $15 \mathrm{~s}$ every 4 min) in human airways in vitro. However, both antagonists attenuated the facilitation of cholinergic contraction by 5 HT (100 $\mu \mathrm{M}, \mathrm{n}=6)$ (fig. 3).

The responses to EFS $(50 \mathrm{~V}, 0.5 \mathrm{~ms}, 1-32 \mathrm{~Hz}$ for $15 \mathrm{~s}$ every $4 \mathrm{~min})$ in vehicle-treated tissues $(n=6)$ remained stable throughout the period of the experiment.

Effect of 5-hydroxytryptamine agonists on cholinergic contraction in human airways in vitro

The effects of selective 5-HT agonists are shown in figure 4 , which depicts the $\%$ facilitation of cholinergic contraction elicited by EFS at $2 \mathrm{~Hz}(50 \mathrm{~V}, 0.5 \mathrm{~ms}, 15 \mathrm{~s})$ in human airways in vitro. 5-Methoxytryptamine (1-100 $\mu \mathrm{M}, \mathrm{n}=6)$ and RS67333 (1-100 $\mu \mathrm{M}, \mathrm{n}=6)$, both agonists at the 5- $\mathrm{HT}_{4}$ receptor, and also 2-methyl-5-HT $(100 \mu \mathrm{M}$, $\mathrm{n}=6$ ), a $5-\mathrm{HT}_{3}$ agonist, produced concentration-dependent facilitation of cholinergic contraction similar to the effects of 5-HT (fig. 4). Sumatriptan $(100 \mu \mathrm{M}, \mathrm{n}=5)$, a 5$\mathrm{HT}_{1 \mathrm{~B} / 1 \mathrm{D}}$ agonist, and RU-24969 $(100 \mu \mathrm{M})$, a 5-HT $1 \mathrm{~A} / 1 \mathrm{~B}$ agonist, had no effect on cholinergic contraction (data not shown).

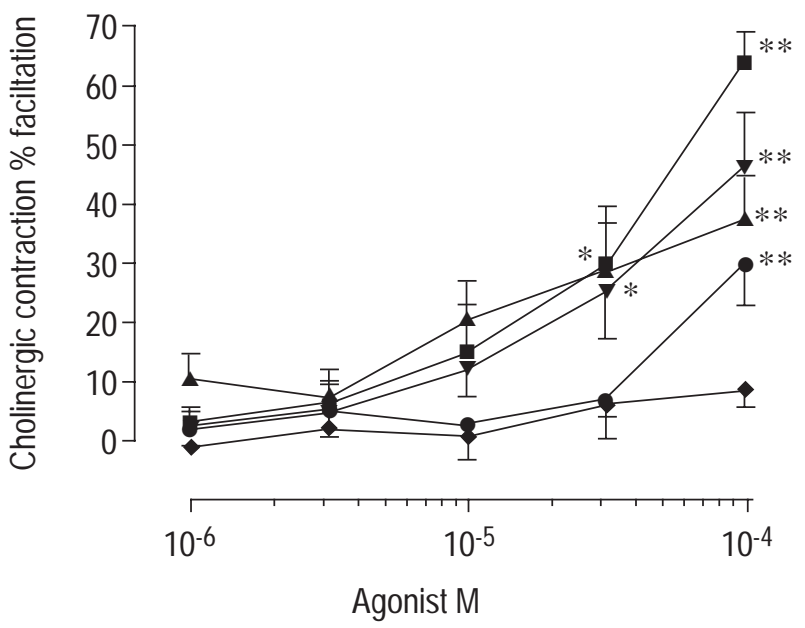

Fig. 4. - Effect of the 5-HT agonists 5-methoxytryptamine 1-100 $\mathrm{uM}$ $(\boldsymbol{\Delta}, \mathrm{n}=6)$ 2-methyl-5-HT 1-100 $\mu \mathrm{M}(\boldsymbol{\bullet}, \mathrm{n}=6) \mathrm{RS} 673331-100 \mu \mathrm{M}(\boldsymbol{\nabla}$, $\mathrm{n}=6)$ and 5 -HT $1-100 \mu \mathrm{M}(\boldsymbol{\square}, \mathrm{n}=5)$ on cholinergic contraction elicited by electrical field stimulation (EFS) $(50 \mathrm{~V}$ at source, $0.5 \mathrm{~ms}, 2 \mathrm{~Hz}$ for 15 s every $4 \mathrm{~min}$ ) versus time control responses $(\diamond, \mathrm{n}=10)$ in human airways in vitro. All agonists produced concentration-dependent facilitation of cholinergic contraction. Data are presented as mean \pm SEM. *: $\mathrm{p}<0.05 ; * *: \mathrm{p}<0.01$ versus control.

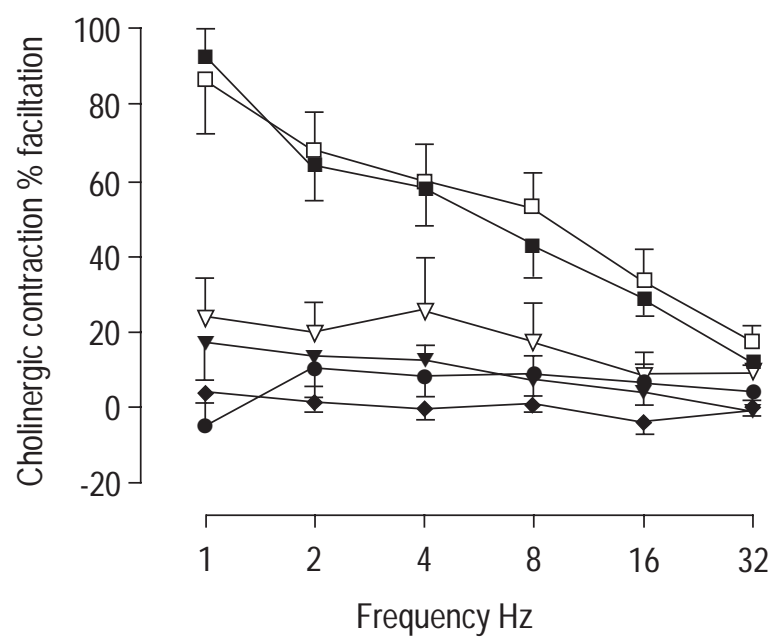

Fig. 5. - Facilitatory effect of $100 \mu \mathrm{M}(\boldsymbol{\square}, \mathrm{n}=8)$ and $10 \mu \mathrm{M}$ 5-HT $(\boldsymbol{\nabla}$, $\mathrm{n}=6)$ on cholinergic contraction elicited by electrical field stimulation (EFS) (50 V at source, $0.5 \mathrm{~ms}, 1-32 \mathrm{~Hz}$ for $15 \mathrm{~s}$ every $4 \mathrm{~min}$ ) in human airways in vitro. Pretreatment with fluoxetine $10 \mu \mathrm{M}(\mathbf{O}, \mathrm{n}=6)$ alone had no effect on cholinergic contraction and fluoxetine also failed to modulate the effect on cholinergic contraction of $100 \mu \mathrm{M}(\square, \mathrm{n}=6)$ and $10 \mu \mathrm{M} 5$-HT $(\nabla, \mathrm{n}=5)$. The responses in control tissues $(\bullet, \mathrm{n}=8)$ remained stable. Data are presented as mean \pm SEM.

The responses to EFS ( $50 \mathrm{~V}, 0.5 \mathrm{~ms}, 2 \mathrm{~Hz}$ for $15 \mathrm{~s})$ in vehicle-treated tissues $(n=6)$ remained stable throughout the period of the experiment.

Effect of fluoxetine and 5-hydroxytryptamine on cholinergic contraction in human airways in vitro

Fluoxetine $(10 \mu \mathrm{M}, \mathrm{n}=6)$ alone had no effect on either basal tone or on cholinergic contraction elicited by EFS ( 50 $\mathrm{V}, 0.5 \mathrm{~ms}, 1-32 \mathrm{~Hz}$ for $15 \mathrm{~s}$ every $4 \mathrm{~min}$ ) in human airways in vitro. Fluoxetine $(10 \mu \mathrm{M}, \mathrm{n}=5)$ also failed to modulate 5HT $(10-100 \mu \mathrm{M})$-induced facilitation of cholinergic contraction in human airways in vitro (fig. 5). The responses to EFS $(50 \mathrm{~V}, 0.5 \mathrm{~ms}, 1-32 \mathrm{~Hz}$ for $15 \mathrm{~s}$ every $4 \mathrm{~min})$ in vehicle-treated tissues $(n=6)$ remained stable throughout the period of the experiment.

Effect of 5-hydroxytryptamine on the concentration/response curve to acetylcholine in human airways in vitro

Ach $(30 \mathrm{nM}-30 \mathrm{mM})$ produced a concentration-dependent contraction of human airways with a maximum contraction tension of $1.9 \pm 0.2 \mathrm{~g}$. Pretreatment with 5 -HT $(300 \mu \mathrm{M})$ had no significant effect on contractile responses to incremental concentrations of Ach (30 nM-30 mM) in human airways in vitro ( $\mathrm{n}=5$, NS) compared to contraction to Ach in control tissues (fig. 6).

\section{Discussion}

Activation of parasympathetic nerves results in the release of acetylcholine, which induces airway smooth muscle contraction through stimulation of muscarinic $\mathrm{M}_{3}$ receptors [19]. Release of Ach upon nerve activation has been shown to be modulated by several endogenous substances including certain peptides and autacoids, such 


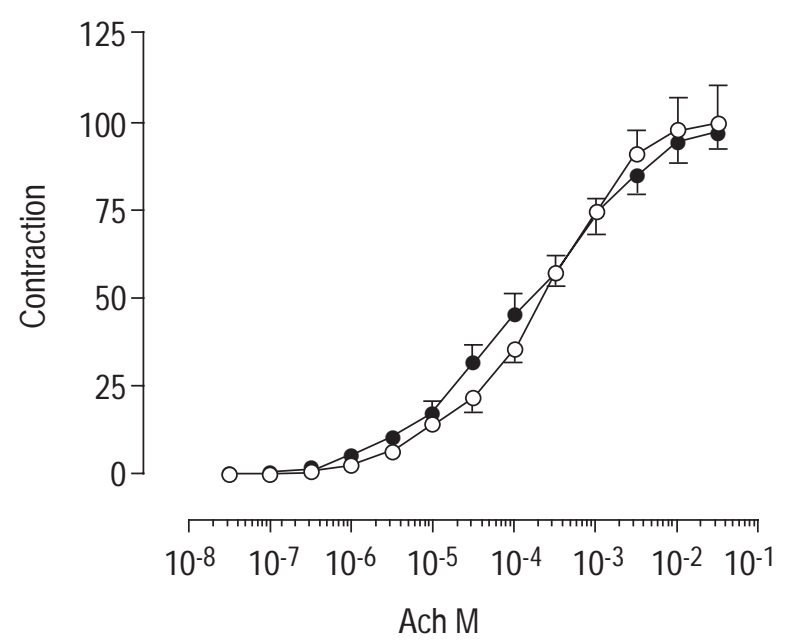

Fig. 6. - Effect of the absence $(\bigcirc)$ or presence (O) of 5-HT $300 \mu \mathrm{M}$ on the cumulative concentration/response curve to exogenously appliced acetylcholine (Ach) $(30 \mathrm{nM}-30 \mu \mathrm{M})$. Data are presented as a mean \pm SEM percentage of the maximal response to Ach $(10 \mathrm{mM})(\mathrm{n}=5)$.

as 5-HT [19]. Numerous reports have demonstrated that 5 -HT is able to potentiate parasympathetic effects on airway smooth muscle via the efferent vagal pathway. 5HT induced bronchoconstriction in dogs in vivo, which was inhibited by cooling of the vagus nerve [20] or by atropine pretreatment [21]. It was also shown that 5-HT enhanced bronchoconstriction induced by vagal stimulation in dogs in vivo, whereas the bronchoconstrictor response to exogenous Ach remained unchanged [22]. These data suggested an interaction of 5-HT with the vagus nerve, which was confirmed in in vitro studies. The 5-HT-induced contraction of airway smooth muscle in rat bronchi and in guinea-pig lung was antagonized by atropine [23, 24]. 5-HT also facilitated contraction of rat bronchi and mouse trachea induced by EFS by stimulation of 5-HT 2 [8] and 5-HT 1 -like [7] receptors respectively. In isolated guinea-pig airways in vitro, stimulation of prejunctional $5-\mathrm{HT}_{3}$ receptors potentiated neuronal cholinergic contractions $[9,10]$. A facilitatory effect of 5HT on cholinergic contraction elicited by EFS at 4 [10] and at $20 \mathrm{~Hz}$ [25] has also been demonstrated in human airways in vitro, but only at higher concentrations of 5HT than in other animal species.

In the present study, 5-HT produced enhancement of isometric cholinergic contractions induced by EFS at different frequencies of stimulation. When the contractile responses were expressed as \% facilitation, the effect of 5HT was more pronounced at lower frequencies. The somewhat smaller potentiating effect of 5-HT on EFS-induced cholinergic contraction at higher frequencies of stimulation may be caused by the degradation of 5-HT. In oxygenated buffer solution EFS generates oxygen molecules, which have been shown to oxidize contractile drugs and to relax preparations [26]. This study also confirms that 5-HT interacts with prejunctional receptors on postganglionic nerves to facilitate Ach release induced by EFS, since 5HT did not affect contractile responses to exogenously applied Ach. These observations are in agreement with those of other studies, using rat, mouse and guinea-pig airways, in which facilitatory effects of 5-HT on parasympathetic neurotransmission have been demonstrated.
In the present study, further characterization of the 5HT receptor subtype involved was also attempted. Over the past ten years, evidence obtained from molecular, biochemical and physiological studies has revealed the existence of 15 5-HT receptor subtypes, which can be subdivided into seven major families (5-HT $\mathrm{H}_{1-7}$ subtypes). Important advances have also been made with the development of potent agonists and antagonists, which bind specific 5-HT receptor subtypes with a high degree of selectivity. In the present study, 5-HT-induced facilitation of cholinergic contraction was significantly antagonized by tropisetron, a $5-\mathrm{HT}_{3}$ and $5-\mathrm{HT}_{4}$ antagonist, confirming the results of TAKAHASHI et al. [10] who only investigated a frequency of stimulation of $4 \mathrm{~Hz}$. Furthermore, extrapolating their findings in guinea-pig airways, TAKAHASHI et al. [10] assumed the presence of a prejunctional $5-\mathrm{HT}_{3}$ in human airways. It is clear, however, that the pharmacological data presented in their study is insufficient for such a conclusion. In the present study, the effect of 5-HT was investigated against full frequency response curves as well as on the cumulative concentration/contraction relationship to exogenously applied Ach. A broad range of selective antagonists and agonists at both $5-\mathrm{HT}_{3}$ and 5$\mathrm{HT}_{4}$ receptors was also used. These compounds and their pharmacological potencies are listed in table 1 [15]. RS 67333 is a novel 5-HT receptor agonist with selectivity for the $5-\mathrm{HT}_{4}$ receptor [16]. GR $125478 \mathrm{D}$ has been described as a potent and selective $5-\mathrm{HT}_{4}$ antagonist [27]. Selective antagonists at both $5-\mathrm{HT}_{3}$ and $5-\mathrm{HT}_{4}$ receptors significantly attenuated the facilitatory effect of 5-HT on cholinergic contraction, although to a somewhat lesser extent than tropisetron. Both selective $5-\mathrm{HT}_{3}$ and $5-\mathrm{HT}_{4}$ agonists mimicked the effect of 5-HT on cholinergic contraction in human airways, but this effect was only evident at relatively high concentrations. Although $5-\mathrm{HT}_{4}$ agonists (5-methoxytryptamine, RS67333) were somewhat more potent than the $5-\mathrm{HT}_{3}$ agonist (2-methyl-5HT), the pharmacological profile of the receptor involved in the present study does not agree exactly with the profile of a $5-\mathrm{HT}_{4}$ receptor subtype, as a facilitatory effect by selective $5-\mathrm{HT}_{3}$ agonists was also noted. This is in agreement with the significant inhibition of 5-HT-induced facilitation of the cholinergic contraction by both selective $5-\mathrm{HT}_{3}$ and $5-\mathrm{HT}_{4}$ antagonists. $5-\mathrm{HT}_{1}$-selective agonists did not affect cholinergic contraction in human airways, confirmed by the lack of effect of methysergide on 5-HT-induced facilitation. Contrary to the assumption of TAKAHASHI et al. [10], these data, therefore, suggest involvement of both prejunctional $5-\mathrm{HT}_{3}$ and $5-\mathrm{HT}_{4}$ receptors located on the postganglionic cholinergic nerves in the potentiation of cholinergic contraction.

Excitatory $5-\mathrm{HT}_{3}$ and $5-\mathrm{HT}_{4}$ receptors on postganglionic parasympathetic nerves have also been demonstrated in isolated guinea-pig colon [28], ileal circular muscle [29] and stomach preparations [30]. Similarly, facilitation of cholinergic neurotransmission in strips of isolated human detrusor muscle [31] as well as in rat stomach fundus [32] is mediated through stimulation of $5-\mathrm{HT}_{4}$ receptors.

In the present study, 5-HT had no significant effect on baseline tension nor on Ach-induced contractions. These findings are in agreement with previous data from LuLICH and PATERSOn [33] who also failed to demonstrate a significant response to 5-HT $(1-100 \mu \mathrm{M})$ in bronchial smooth muscle preparations. RAFFESTIN et al. [34], on the other 
hand, observed that 5-HT (100 nM-10 $\mu \mathrm{M})$ caused relaxation of bronchial preparations precontracted with Ach $(50 \mu \mathrm{M})$. In this study, however, large bronchial preparations were treated under an initial load of $5 \mathrm{~g}$, in contrast to $2 \mathrm{~g}$ in the present study. As demonstrated previously, relaxant responses in human airways in vitro increase in magnitude with increasing resting tension [35], which could account for this discrepancy from the present findings.

Significant neuronal uptake of 5-HT into sympathetic nerve terminals as well as extraneuronal uptake of 5-HT has been shown in various preparations [36]. In mouse trachea, pretreatment with the 5-HT uptake inhibitor fluvoxamine tended to increase the potentiation of cholinergic contraction by $5-\mathrm{HT}$, although this effect did not reach significance [7]. In guinea-pig airways in vitro fluoxetine, a selective 5-HT uptake inhibitor, significantly facilitated 5-HT-induced inhibition of NANC contraction [17]. In the present study, however, fluoxetine, at a concentration which was much higher than the concentration required to inhibit ${ }^{3} \mathrm{H}-5-\mathrm{HT}$ uptake in rat brain synaptosomal preparations [37], failed to modulate 5-HT-induced facilitation of cholinergic contraction in human airways in vitro. These data argue against the presence of an important 5-HT uptake mechanism in human airways.

In conclusion, evidence has been found for the existence of both prejunctional $5-\mathrm{HT}_{3}$ and $5-\mathrm{HT}_{4}$ receptors on postganglionic cholinergic nerves, which enhance the EFSinduced cholinergic contraction in human airways in vitro.

Although the significance of 5-hydroxytryptamine in the pathophysiology of obstructive airway diseases remains to be elucidated, the elevated plasma level in asthmatic patients [13] and the release of 5-hydroxytryptamine from platelets during allergic reactions [38] may have a role in facilitating bronchoconstriction in these conditions.

\section{References}

1. Sirek A, Sirek OV. Serotonin: a review. Can Med Assoc J 1970; 102: 846-849.

2. Lauweryns JM, de Bock V, Verhofstad AA, Steinbusch HW. Immunohistochemical localization of serotonin in intrapulmonary neuro-epithelial bodies. Cell Tissue Res 1982; 226: 215-223.

3. Watts SW, Cohen ML. Characterization of the contractile serotonergic receptor in guinea pig trachea with agonists and antagonists. J Pharmacol Exp Ther 1992; 260: 11011106.

4. Grundstrom N, Andersson RG, Wikberg JE. Pharmacological characterization of the autonomous innervation of the guinea pig tracheobronchial smooth muscle. Acta Pharmacol Toxicol 1981; 49: 150-157.

5. Pype JL, Verleden GM, Demedts MG. 5-HT modulates noncholinergic contraction in guinea pig airways in vitro by prejunctional 5 - $\mathrm{HT}_{1}$-like receptor. J Appl Physiol 1994; 77: 1135-1141.

6. Meade CJ. The mechanism by which epinastine stops an adenosine analog contracting BDE rat airways. Am J Respir Crit Care Med 1998; 157: 522-530.

7. Van Oosterhout AJ, Hofman G, Woutersen-Van Nijnanten

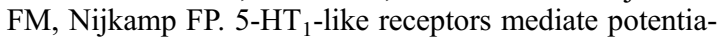
tion of cholinergic nerve-mediated contraction of isolated mouse trachea. Eur J Pharmacol 1991; 209: 237-244.

8. Szarek JL, Zhang JZ, Gruetter CA. 5-HT2 receptors augment cholinergic nerve-mediated contraction of rat bronchi. Eur J Pharmacol 1993; 231: 339-346.

9. Rizzo CA, Kreutner W, Chapman RW. 5- $\mathrm{HT}_{3}$ receptors augment neuronal, cholinergic contractions in guinea pig trachea. Eur J Pharmacol 1993; 234: 109-112.

10. Takahashi T, Ward JK, Tadjkarimi S, Yacoub MH, Barnes PJ, Belvisi MG. 5-Hydroxytryptamine facilitates cholinergic bronchoconstriction in human and guinea pig airways. Am J Respir Crit Care Med 1995; 152: 377-380.

11. Rosen S. The carcinoid syndrome. JAMA 1988; 260: 1602-1605.

12. Cushley MJ, Wee LH, Holgate ST. The effect of inhaled 5-hydroxytryptamine (5-HT, serotonin) on airway calibre in man. Br J Clin Pharmacol 1986; 22: 487-490.

13. Lechin F, van der Dijs B, Orozco B, Lechin M, Lechin AE. Increased levels of free serotonin in plasma of symptomatic asthmatic patients. Ann Allergy Asthma Immunol 1996; 77: 245-253.

14. Cazzola M, D'Amato G, Lobefalo G, et al. Ketanserin, a new blocking agent of serotonin $\mathrm{S}_{2}$-receptors. Respiratory functional effects in chronic obstruction of the airways. Chest 1987; 92: 863-866.

15. Hoyer D, Clarke DE, Fozard J, et al. International union of pharmacology classification of receptors for 5-HT (serotonin). Pharmacol Rev 1994; 46: 157-203.

16. Eglen RM, Bonhaus DW, Johnson LG, Leung E, Clark RD. Pharmacological characterization of two novel and potent $5-\mathrm{HT}_{4}$ receptor agonists, RS67333 and RS67506, in vitro and in vivo. Br J Pharmacol 1995; 115: 1387-1392.

17. Dupont LJ, Pype JL, Demedts MG, Verleden GM. Fluoxetine enhances the 5 HT-induced inhibition of the non-cholinergic contraction in guinea-pig airways in vitro. Eur Respir J 1996; 9: 133S (Abstract).

18. Verleden GM, Pype JL, Deneffe G, Demedts MG. Effect of loop diuretics on cholinergic neurotransmission in human airways in vitro. Thorax 1994; 49: 657-663.

19. Barnes PJ. Modulation of neurotransmission in airways. Physiol Rev 1992; 72: 699-729.

20. Hahn HL, Wilson AG, Graf PD, Fischer SP, Nadel JA. Interaction between serotonin and efferent vagus nerves in dog lungs. J Appl Physiol 1978; 44: 144-149.

21. Islam MD, Melville GN, Ulmer WT. Role of the atropine in antagonizing the effect of 5-HT on bronchial and pulmonary vascular systems. Respiration 1974; 31: 47-59.

22. Sheller JR, Holtzman MJ, Skoogh BE, Nadel JA. Interaction of serotonin with vagal- and Ach-induced bronchoconstriction in canine lungs. J Appl Physiol 1982; 52: 964-966.

23. Aas P. Serotonin induced release of acetylcholine from neurons in the bronchial smooth muscle of the rat. Acta Physiol Scand 1983; 117: 477-480.

24. Bhattacharya BK. A pharmacological study on the effect of 5-HT and its antagonists on the bronchial musculature. Arch Int Pharmacodyn 1955; 103: 357-369.

25. Zorychta E, Richardson JB. Control of smooth muscle in human airways. Bull Eur Physiopathol Respir 1980; 16: 581-586.

26. Greenberg B, Rhoden K, Barnes PJ. Activated oxygen molecules generated by electrical field stimulation affect vascular smooth muscle. J Mol Cell Cardiol 1986; 18: 975-981.

27. Schiavi GB, Brunet S, Rizzi CA, Ladinsky H. Identification of serotonin $5-\mathrm{HT}_{4}$ recogition sites in the porcine caudate nucleus by radioligand binding. Neuropharmacol 1994; 33: 543-549.

28. Briejer MR, Schuurkes JA. 5- $\mathrm{HT}_{3}$ and 5- $\mathrm{HT}_{4}$ receptors and cholinergic and tachykinergic neurotransmission in 
the guinea-pig proximal colon. Eur J Pharmacol 1996; 308: $173-180$

29. Eglen RM, Swank SR, Walsh LK, Whiting RL. Characterization of 5- $\mathrm{HT}_{3}$ and 'atypical' 5-HT receptors mediating guinea-pig ileal contractions in vitro. Br JPharmacol 1990; 101: 513-520.

30. Buchheit K, Buhl T. Stimulant effects of 5-HT on guineapig stomach preparations in vitro. Eur J Pharmacol 1994; 262: 91-97.

31. Candura SM, Messori E, Franceschetti GP, et al. Neural $5-\mathrm{HT}_{4}$ receptors in the human isolated detrusor muscle: effects of indole, benzimidazolone and substituted benzamide agonists and antagonists. Br J Pharmacol 1996; 118: 1965-1970.

32. Amemiya N, Hatta S, Takemura H, Ohshika $H$. Characterization of the contractile response induced by 5-methoxytryptamine in rat stomach fundus strips. Eur $J$ Pharmacol 1996; 318: 403-409.

33. Lulich KM, Paterson JW. An in vitro study of various drugs on central and peripheral airways of the rat: a comparison with human airways. Br J Pharmacol 1980; 68: 633-636.

34. Raffestin B, Cerrina J, Boullet C, Labat C, Benveniste J, Brink C. Response and sensitivity of isolated human pulmonary muscle preparations to pharmacological agents. $J$ Pharm Exp Ther 1985; 233: 186-194.

35. Watson N, Magnussen H, Rabe KF. The relevance of resting tension to responsiveness and inherent tone of human bronchial smooth muscle. Br J Pharmacol 1998; 123: 694-700.

36. Fukuda S, Su C, Lee JF. Mechanisms of extraneuronal serotonin uptake in the rat aorta. J Pharmacol Exp Ther 1986; 239: 264-269.

37. Leonard BE. Pharmacological differences of serotonin reuptake inhibitors and possible clinical relevance. Drugs 1992; 43 Suppl 2: 3-9.

38. Malmgren R, Grubbström J, Olsson P, Theorell H, Tornling G, Unge G. Defective serotonin (5-HT) transport mechanism in platelets from patients with endogenous and allergic asthma. Allergy 1982; 37: 29-39. 